Joanna Grochala*

Kraków

\title{
Przebaczenie sobie w kontekście rozwoju osobistego w wieku senioralnym
}

Proces, który w literaturze gerontologicznej funkcjonuje pod nazwą przygotowania do starości, oznacza przede wszystkim przygotowanie do realizacji różnych zadań rozwojowych, specyficznych dla tego etapu życia oraz adaptację do zmian związanych z procesem starzenia się. Proces ten stanowi przedmiot zainteresowania gerontopedagogiki, w obszarze której jest on opisywany jako całożyciowy i wielopłaszczyznowy, a ponadto wymagający wspierania w konkretnych działaniach pedagogicznych. W związku $\mathrm{z}$ tym refleksja nad tego rodzaju przygotowaniem powinna być rozwijana przez pedagogów, pracujących z osobami na każdym etapie życia. Wszak to, jak będzie przebiegał bilans życiowy u schyłku życia człowieka, jest między innymi efektem wielu lat jego pracy w sferze rozwoju osobistego i refleksji egzystencjalnej lub z kolei ich braku.

Zgodnie z koncepcją Erika Eriksona oraz Roberta Havighursta każdy okres życia charakteryzuje się różnymi zadaniami rozwojowymi ${ }^{1}$. Jeśli chodzi o wiek senioralny, najważniejszymi zadaniami są: umiejętne rozwiązanie problemu przejścia na emeryturę, akceptacja własnych możliwości i ogra-

* Mgr Joanna Grochala jest doktorantką na Wydziale Filozoficznym w Instytucie Pedagogiki Uniwersytetu Jagiellońskiego w Krakowie. Adres: Instytut Pedagogiki Uniwersytetu Jagiellońskiego, ul. Batorego 12,31-135 Kraków; e-mail: joanna.grochala@doctoral.uj.edu.pl.

${ }^{1}$ Por. Alina Matlakiewicz, Hanna Solarczyk-Szewc, Dorośli ucza się inaczej (Toruń: Wydawnictwo CKU, 2005), 15. 
niczeń, autoedukacja, odnajdywanie sensu życia, osiąganie coraz głębszego poczucia tożsamości, twórcze i zdrowe korzystanie z wolnego czasu, utrzymywanie kontaktów i przystosowanie do zmieniających się z wiekiem ról społecznych. Zadania te $\mathrm{w}$ dużej mierze stanowią komponenty bardziej ogólnego pojęcia, jakim jest samorealizacja, która z kolei łączy się z pojęciem rozwoju osobistego prowadzącego do utrzymania lub poprawy poziomu jakości życia.

W badaniach nad jakością życia coraz częściej wskazuje się na znaczenie wymiarów egzystencjalnych - ważna staje się ocena własnego życia przez osobę starszą ze względu na jego sens. Jakość życia w znacznym stopniu determinowana jest tym, jakie znaczenie człowiek starszy przypisuje swojemu dotychczasowemu życiu, różnym zdarzeniom i sytuacjom, oraz czy ma poczucie jego sensu i wartości ${ }^{2}$.

Wiek senioralny jest optymalnym okresem dla podjęcia takiej egzystencjalnej refleksji, przyjrzenia się własnej historii życia i dokonania reinterpretacji dotychczasowych doświadczeń z aktualnej, szerokiej perspektywy, w kontekście ugruntowanych wartości. Tak można rozumieć sens bilansu życia w wieku dojrzałym. Pojęcie to Stanisława Steuden definiuje ponadto jako podsumowywanie życia, zawierające:

poznawcze, emocjonalne i behawioralne odniesienie się do własnego życia w aspekcie sukcesów i niepowodzeń. [...] Jakość bilansu życiowego u ludzi starych jest wyrazem ich subiektywnego odniesienia do własnego życia. Pozytywna bądź negatywna treść bilansu życiowego jest miarą skuteczności realizacji celów, które osoba uznała za ważne w życiu, a jednocześnie wyrazem integracji osobowości ${ }^{3}$.

Subiektywne odniesienie do własnej biografii łączy się właśnie z nadawaniem znaczeń swoim przeszłym doświadczeniom, interpretacją swojej dotychczasowej historii $\mathrm{w}$ kontekście wyznawanych wartości, $\mathrm{w}$ procesie tak zwanego przeglądu życia. Odniesienie to wiąże się także z poziomem otwartości na pozostałe perspektywy czasowe - teraźniejszość i przyszłość. Jednym $\mathrm{z}$ naczelnych zadań rozwojowych w wieku senioralnym jest (we-

${ }^{2}$ Stanisława Steuden, Psychologia starzenia się i starości (Warszawa: PWN, 2011), 169.

3 Tamże, 111. 
dle koncepcji Erika Eriksona ${ }^{4}$ ) wzmocnienie integralności Ego oraz ochrona przed rozpaczą i dezintegracją. Można to odnieść do procesu wspierania seniorów w umacnianiu poczucia ich tożsamości czy też poczucia bycia sobą, które „łączy się z wysiłkiem scalania różnych doświadczeń zdobywanych na przestrzeni całego życia"s. Można stwierdzić, że pozytywne efekty autobiograficznej retrospekcji, a zatem wspomniana integracja i możliwość uczenia się z własnej biografii, zależą między innymi od poziomu indywidualnej gotowości i otwartości na akceptację trudnych i bolesnych doświadczeń, a także własnych błędów i słabości. Owa akceptacja łączy się zaś z umiejętnością przebaczenia.

Kazimierz Mrówka, analizując fenomen przebaczenia, wskazuje na jego interpersonalny charakter, odnosząc go do relacji: bliźni-bliźni lub relacji z Bogiem. Przebaczenie jako bezinteresowny i bezgraniczny dar serca jest „zaproszeniem do odtworzenia relacji zniszczonej przez wyrządzoną krzyw-

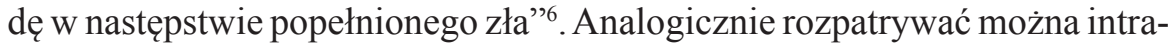
personalny, wewnętrzny charakter przebaczenia, związany z odtworzeniem relacji z samym sobą, przywróceniem wewnętrznej integracji i harmonii, które zostały zaburzone. Przebaczenie może zatem dotyczyć tak wymiaru interpersonalnego, związanego z przebaczeniem win sprawcom cierpienia, jak i wymiaru intrapersonalnego, łączącego się z przebaczeniem samemu sobie tego, co uznaje się za własne przewinienia. Właśnie ten drugi wymiar w kontekście rozwoju osobistego osób starszych, rozpatrywany w świetle chrześcijańskiej refleksji filozoficznej i psychologicznej, stanowi przedmiot niniejszej pracy.

Głównym celem pracy jest podkreślenie istotnej roli przebaczenia $\mathrm{w}$ wymiarze intrapersonalnym $\mathrm{w}$ procesie przygotowania do rozwojowego i twórczego przeżywania okresu emerytalnego. Proces przebaczenia samemu sobie jawi się jako zasadniczy dla przygotowania do konstruktywnego i twórczego bilansu życia, a także samorealizacji i utrzymania wysokiego poziomu jakości życia na jego ostatnim etapie.

4 Tamże, 52.

5 Tamże, 194.

${ }^{6}$ Kazimierz Mrówka, Filozoficzny sens przebaczenia (Tarnów: Wydawnictwo Biblos, 2008), 28. 


\section{Pojęcie przebaczenia}

Rzeczownik „przebaczenie” w Słowniku języka polskiego oznacza: „przestać się za coś gniewać na kogoś, darować komuś jakąś winę, puścić coś w niepamięć; wybaczyć" ". Jak wskazuje Kazimierz Mrówka, w języku polskim pojęcie to odnosi się do widzenia, a więc „niebaczenia”, „odwrócenia wzroku”, ,przeoczenia”, zaś w językach łacińskim i germańskim odnosi się głównie do „dawania”, „obdarowania”, co związane jest ze specyficzną cechą tego aktu, jaką jest bezinteresowność. W definicji czasownika „przebaczyć” pojawia się niekiedy odniesienie do emocji oraz do pamięci, na przykład: „przestać się za coś gniewać na kogoś, puścić coś w niepamięć”. Podobnie $\mathrm{w}$ definicji angielskiego pojęcia forgive ma miejsce odniesienie przede wszystkim do kresu uczucia złości i urażenia na kogoś (forgive $($ verb) - „stop feeling angry or resentful towards someone for (an offence, flaw or mistake)" $)^{10}$.

Fenomen przebaczenia analizowany jest na różnych płaszczyznach, przede wszystkim psychologicznej oraz teologicznej. Według Kazimierza Mrówki pojęcie to zakorzenione jest najmocniej w tradycji judeochrześcijańskiej, a zatem związane z ideą miłosiernego i przebaczającego grzechy Boga. „Nawet jeśli akt przebaczenia dokonuje się w wymiarze świeckim, to nadal zachowuje cechy przebaczenia religijnego" "11, łączony jest bowiem często $\mathrm{z}$ aktem łaski i darem.

Przebaczenie odróżniane jest od sprawiedliwości samej dla siebie, regulującej relacje mechanicznie. Natomiast sprawiedliwość i przebaczenie jawią się jako zjawiska komplementarne, gdzie sprawiedliwość stanowi cel przebaczenia. Pojęcie przebaczenia odróżniane jest ponadto przez różnych autorów od zapomnienia, zrozumienia, związanego z usprawiedliwieniem, a także od pojednania. Zapomnienie jest przeciwne idei przebaczenia ze względu na to, że pamięć o błędach lub krzywdach jest niezbędna dla uniknięcia ich w przyszłości (co pozostaje w zgodzie ze słowami Psalmu: „Uznaję bowiem moją nieprawość, a grzech mój mam zawsze przed sobą"

7 Tamże, 17.

${ }^{8}$ Por. tamże.

9 Stownik Języka Polskiego, t. 2, red. Marek Szymczak (Warszawa: PWN, 2002), 909.

${ }^{10}$ The New Oxford Dictionary of English, red. Judy Pearsall (Oxford: Clarendon Press, 1998), 719.

${ }^{11}$ Mrówka, Filozoficzny, 27. 
(Ps 51(50)). W związku z tym ,przebaczyć, znaczy pamiętać przeszłość po to, by ją przyswoić i uczynić z niej część własnej historii. Taka pamięć jest pracą kreatywną, a nie tylko nadaremnym powtarzaniem wydarzenia z przeszłości"12.

Według Kazimierza Mrówki przebaczenie jest wrogiem zrozumienia, które wiąże się z mechanizmem obronnym racjonalizacji i usprawiedliwiania, a to z kolei potęguje konflikt wewnętrzny i może implikować banalizowanie i relatywizowanie winy ${ }^{13}$. Autor stanowczo stwierdza: ,zrozumienie jest kolejną formą pseudoprzebaczenia, które $\mathrm{w}$ akcie relatywizowania, a więc unieważniania zła, profanuje autentyczne wybaczenie"14. Stwierdzenie to wydaje się kontrowersyjne, zwłaszcza gdy analizujemy mechanizm przebaczenia samemu sobie, jako pogłębianie zrozumienia własnych doświadczeń i leżących u ich podstawy wyborów przez siebie dokonanych. Powstaje pytanie, czy rzeczywiście każda próba odnalezienia przyczyn błędu lub krzywdy oznacza automatyczne unieważnienie zła?

Przebaczenie jest fenomenem wieloaspektowym, trudnym do empirycznej analizy i obejmującym różne sfery życia człowieka. Możliwe jest ono tylko w odniesieniu do człowieka rozumianego jako osoba, który charakteryzuje się wolnością, godnością i podmiotowością. W refleksji chrześcijańskiej przebaczenie zyskuje szczególny, transcendentny wymiar. „Chrześcijańskie doświadczenie przebaczenia nie kończy się na darmowym otrzymaniu daru od Boga, lecz przechodzi od doświadczenia biernego, kiedy nam zostaje przebaczone, do doświadczenia aktywnego, kiedy to my przebaczamy, jako zadania, do którego każdy człowiek jest powołany"'15. W antropologii chrześcijańskiej przebaczenie jest zatem aktem, który w każdej relacji trzeba stale ponawiać i który jest warunkiem uzdrowienia i osiągnięcia pełni życia.

\section{Specyfika aktu przebaczenia samemu sobie w kontekście nadchodzącej starości}

Jak zauważa Annalisa Giulianini, w literaturze na temat przebaczenia często pomijana jest problematyka przebaczenia wewnętrznego, a więc prze-

12 Annalisa Giulianini, O przebaczeniu, czyli jak uleczyć duszę (Kraków: Bratni Zew Wydawnictwo Franciszkanów, 2010), 21.

13 Mrówka, Filozoficzny, 51.

14 Tamże, 51.

15 Giulianini, O przebaczeniu, 98. 
baczenia udzielanego samemu sobie ${ }^{16}$. Tymczasem ta umiejętność w pewnym sensie determinuje gotowość do pozostałych rodzajów przebaczenia. „Umiejętność zaakceptowania i przebaczenia sobie samemu jest nierozerwalnie związana z umiejętnością przebaczania i pojednania z innymi i z Bogiem, niejako dla potwierdzenia, że nie można kochać i przebaczać innym, jeśli najpierw nie pokocha się i nie przebaczy sobie"17. Akt przebaczenia samemu sobie jawi się jako szczególnie istotny w kontekście zbliżania się do kresu życia i dokonywania tego, co zwiemy przeglądem życia czy też bilansem życia.

Pozytywne lub negatywne odniesienie do własnej biografii implikuje określoną postawę wobec teraźniejszości oraz przyszłości, w tym wobec własnej starości. Innymi słowy, aktualny stosunek do starości w ogóle, jak również do siebie samego w starości, wynika w dużej mierze z poziomu akceptacji swojej historii życia. „Jeśli osoba nie czuje się zagrożona faktem przemijania oraz treścią bilansu życia, przyjmuje postawę pozytywną do własnej starości, w tym także do przyszłości. Jeśli jednak w ocenie osoby jej życie jest pasmem wydarzeń negatywnych, od których trudno się uwolnić, wówczas może narastać postawa pesymizmu, rezygnacji, wrogości, izolacji od siebie i świata"18. Wydaje się, że im więcej obszarów niezintegrowanych z całością biografii, z którymi trudno się skonfrontować i które trudno zaakceptować, tym większy problem z osiągnięciem wewnętrznej harmonii. Im bardziej zaciemniony obraz siebie samego w przeszłości, który skrywa mroczne obszary nieprzebaczenia, tym zapewne trudniejsze budowanie aktualnego realistycznego, ale też pozytywnego obrazu siebie. Powstaje pytanie: czy w ogóle można podążać ścieżką rozwoju osobistego i dążyć do samorealizacji bez aktu przebaczenia nie tylko osobom, które zawiniły przeciwko nam, ale także samemu sobie?

Negatywna interpretacja swoich dotychczasowych doświadczeń, w tym także własnych błędów, zamyka de facto możliwość twórczego i otwartego podejścia do własnej przyszłości oraz życia pełnią teraźniejszości, a to z kolei uniemożliwia osiągnięcie psychicznego dobrostanu. Według Anselma Grüna „przebaczenie sobie samemu bywa niekiedy trudniejsze niż przebaczenie komuś innemu. Jest ono jednak warunkiem tego, byśmy świadomie

\footnotetext{
16 Tamże, 123.

17 Tamże.

${ }^{18}$ Steuden, Psychologia, 113.
} 
i rozważnie mogli żyć teraźniejszą chwilą, nie zmąconą przez przeszłą winę, którą podświadomie ciągle jeszcze sobie wyrzucamy" ${ }^{19}$.

Postrzeganie swojego życia w kategoriach przegranej lub porażki wiąże się często z niskim poziomem poczucia sprawstwa, kontroli i wpływu na wydarzenia. Dominuje wówczas raczej odczucie bycia ofiarą zewnętrznych negatywnych uwarunkowań, splotu niesprzyjających okoliczności. Postawa taka może sprzyjać utrwaleniu syndromu wyuczonej bezradności (zgodnie $\mathrm{z}$ teorią Martina Seligmana) ${ }^{20}$, a to z kolei może prowadzić do wzmocnienia postawy bierności, zależności od pomocy innych osób lub instytucji czy też postawy roszczeniowej. Można uznać, że przy tego rodzaju odniesieniu do własnej biografii brakuje poczucia wewnętrznej wolności i elastyczności, a dominuje usztywnienie czy też tak zwana petryfikacja ducha. Tymczasem „przebaczenie uwalnia od wewnętrznego nieprzyjaciela i jest aktem, poprzez który człowiek staje się bardziej wolny. [...] Jest to kreatywny akt, który przekształca ludzi z więźniów przeszłości w osoby spokojne, pamiętające o przeszłości”"21. Przebaczenie nie oznacza bowiem zapomnienia o własnej winie, ale pamięć uwolnioną od cierpienia, związanego z poczuciem winy i złością.

Paul Guerin ukazuje szansę, jaka otwiera się przed starzejącym się człowiekiem. „W wieku dojrzałym dochodzi do życiowego nawrócenia: dokonuje się powrót, ponowne odkrycie, nowe ujęcie samego siebie, rzeczywiste pojednanie ze swym losem, z tym, czym się staliśmy" ${ }^{22}$. Stwierdzenie to ma raczej charakter postulatywny, ponieważ nie każda osoba starsza rzeczywiście osiąga stadium pojednania ze sobą. Jednak można uznać, że to właśnie jest etap, na którym człowiek ma optymalne warunki i zasoby dla takiego pojednania.

Anselm Grün rozróżnia pojęcia przebaczenia i pojednania. Przebaczenie odnosi się wprost do winy i oznacza usunięcie tej winy, uwolnienie się od niej, zaś pojednanie dotyczy przywrócenia wspólnoty, umożliwienia ponownego spotkania ${ }^{23}$. Przebaczenie sobie byłoby zatem wstępem do naprawy relacji z samym sobą, a co za tym idzie - z innymi osobami, zaś w wymiarze duchowym $-\mathrm{z}$ transcendencją. Byłby to także punkt wyjścia dla integracji własnych doświadczeń. Akceptacja własnego starzenia się wiąże się zatem

\footnotetext{
19 Anselm Grün, Przebacz samemu sobie (Kraków: WAM, 2003), 41.

${ }^{20}$ Por. Gerd Mietzel, Wprowadzenie do psychologii (Gdańsk: GWP, 2003), 174.

${ }^{21}$ Giulianini, O przebaczaniu, 31.

22 Paul Guerin, Wiek dojrzały jako wyzwanie duchowe (Kraków: eSPe, 2003), 97.

${ }^{23}$ Por. Mrówka, Filozoficzny, 26.
} 
z pojednaniem ze sobą i własną historią, stanowiąc część szerzej pojętej samoakceptacji.

Według Grüna pojednanie z sobą samym oznacza najpierw pogodzenie się z własną historią. Jest to trudne tym bardziej, w im większym stopniu własna interpretacja tej historii znajduje się w konflikcie z wyznawanymi wartościami i ideałami. „Kiedyś jednak musimy się pogodzić ze wszystkim, cośmy przeżyli i przecierpieli. Tylko wtedy, kiedy będziemy gotowi pogodzić się również z naszymi ranami, mogą się one zmienić"24. Wynika z tego, że dopóki ów proces pogodzenia nie nastąpi, dopóty cierpienie wynikające z przeżywania minionych doświadczeń będzie się stale odnawiać i nie pozwoli osobie na osiągnięcie spokoju i zakorzenienia w teraźniejszości.

Szczera akceptacja swej przeszłości i sprawiedliwy podział odpowiedzialności mogą wspaniale ubogacić teraźniejszość: łagodność wobec siebie, tolerancyjność wobec innych, okazywanie im zrozumienia, kiedy błądzą, rozsądek w podejściu do osób i instytucji, odkrywanie pozytywnych cech u ludzi, z którymi przyszło nam żyć, a w końcu być może doznanie pokoju wewnętrznego, danego nam przez Ducha ${ }^{25}$.

Wszystkie wymienione cechy i postawy, stanowiące efekt samoakceptacji, kojarzą się z pojęciami dobrostanu, samorealizacji i mądrości życiowej, a zatem przejawów wysokiej jakości życia w wieku senioralnym.

\section{Przebaczenie sobie w kontekście integracji własnego ,cienia” jako wyzwanie w wieku dojrzałym}

Według Eriksona „spójność ego wymaga pogodzenia się nie tylko z własnymi sukcesami, ale także z porażkami i frustracjami" ${ }^{\prime 26}$. Tymczasem częstym problemem jest akceptacja tej właśnie sfery własnego życia, która nie stanowi dla osoby powodu do dumy, a dotyczy jej słabości, nieporadności, złych decyzji, kompleksów i trudnych emocji. Proces prowadzący do przebaczenia łączy się z poszerzaniem świadomości na swój temat, co jest pracą bolesną ze względu na odkrywaną w samym sobie niedoskonałość.

\footnotetext{
${ }^{24}$ Tamże, 34.

25 Guerin, Wiek, 86.

${ }^{26}$ Steuden, Psychologia, 113.
} 
Akceptacja siebie samego związana jest wszakże z akceptacją swoich słabości i wad.

Carl Gustav Jung analizuje problem akceptacji tak zwanego cienia jako tego, co „wykluczyliśmy z życia, ponieważ nie odpowiadało naszemu wyobrażeniu o nas samych [...]. Najpóźniej w połowie swego życia stajemy w obliczu wezwania, by stawić cieniowi czoło i pogodzić się z nim. Jeśli na to wyzwanie nie odpowiemy, popadniemy w chorobę, pojawi się w nas rozszczepienie i staniemy się wewnętrznie rozdarci" ${ }^{27}$. Stwierdzenie to akcentuje wiodące wyzwanie wieku dojrzałego, a jest nim akceptacja i integracja tego, z czym na wcześniejszych etapach człowiek nie miał odwagi się skonfrontować. Postulat ten wzmocniony jest poprzez wskazanie możliwych konsekwencji braku takiej akceptacji, także dla szeroko rozumianego zdrowia jednostki.

Również Anselm Grün pisze o słabościach, wadach, tłumionych popędach i pragnieniach jako wewnętrznym nieprzyjacielu, z którym należy się pojednać, w przeciwieństwie do wypierania i zaprzeczania ich istnieniu. „Muszę się nieustannie jednać ze sobą i swymi wewnętrznymi nieprzyjaciółmi. W przeciwnym razie będzie w pewnym momencie za późno. Wtedy rozdarcie wewnętrzne stanie się tak wielkie, że żadne pojednanie nie będzie już możliwe"28.

Według Pascala Ide, ,przebaczenie samemu sobie jest zbyt rzadkie. Ileż agresji skierowanej na bliźniego jest tylko wyrównaniem rachunków z samym sobą, do czego nie śmiemy się przyznać ani się poprawić: jesteśmy tak bardzo jasno ukierunkowani na naprawianie u bliźniego rany czy winy, które sami posiadamy" ${ }^{29}$. Słowa te nawiązują do ewangelicznej prawdy o niedostrzeganiu „belki w swoim oku”, jako zaślepieniu na wiedzę o własnych słabościach i jednocześnie wyolbrzymianiu ,ź́dźbła w oku bliźniego”, jako potępianiu najdrobniejszych nawet słabości innych ludzi. Taka koncepcja genezy konfliktów i agresji między ludźmi skłania do rewizji własnych intencji i zachowań w relacjach interpersonalnych pod kątem ewentualnego mechanizmu projekcji, a więc przenoszenia czy też rzutowania własnych wad na inne osoby.

Zdaniem Paula Guerina ,należyte zrozumienie swej ciemnej strony prowadzi do dosyć zadziwiających zmian. [...] Chodzi o prawdziwe słuchanie, bez uprzedzeń, bez przyjmowanych z góry założeń. Życie bowiem narzucało

\footnotetext{
27 Grün, Przebacz, 37.

28 Tamże, 24.

${ }^{29}$ Pascal Ide, Czy możliwe jest przebaczenie? (Kraków: WAM, 2000), 164.
} 
nam pewne wybory i część samych siebie pozostawiliśmy odłogiem. Ów wyparty «cień» brutalnie o sobie przypomina, niczym raniące wspomnienie, stara blizna" ${ }^{30}$. Wśród wielu osób starszych często można zaobserwować postawę naznaczoną narzekaniem, wynikającym między innymi z frustracji: $\mathrm{z}$ niezaspokojonych potrzeb, $\mathrm{z}$ niezrealizowanych planów, z poczucia winy związanego z popełnionymi $\mathrm{w}$ życiu błędami. Ruminowanie negatywnych doświadczeń, polegające na ciągłym powracaniu do nich w pamięci lub negatywne projekcje z przeszłości na teraźniejszość przyczyniają się do pogorszenia samopoczucia psychofizycznego i blokują możliwość osobistego rozwoju. Jak twierdzi Paul Guerin,

należałoby niejako przewrócić kartkę, zacząć nowe życie, nie atakując i nie obwiniając się za własną przeszłość. Działaliśmy, wychowywaliśmy, budowaliśmy, sadziliśmy, kochaliśmy. I jakoś zapominaliśmy przy tym o sobie. Dawaliśmy, nie zastanawiając się zbytnio, co otrzymujemy w zamian. Teraz otwiera się przed nami nowy etap życia: pewien powrót do siebie, odnalezienie siebie, pogodzenie ze sobą i odróżnienie się od drugiego człowieka ${ }^{31}$.

\section{Trudne emocje i walka wewnętrzna na drodze do przebaczenia samemu sobie}

W ujęciu psychoanalitycznym przebaczenie kumuluje i wzmacnia energię i jest związane z Erosem - siłą witalną i kreatywną. Z kolei nienawiść niszczy i pochłania energię i jest związana z Tanatosem - destrukcyjną si$\mathrm{ją}^{32}$. Postawa usztywnienia i niepogodzenia $\mathrm{z}$ własną historią łączy się także z egocentrycznym czy wręcz narcystycznym skupieniem na sobie, co znacząco ogranicza perspektywę, a może wprowadzać deformacje w aktualnym postrzeganiu rzeczywistości. Tymczasem ,przebaczenie przełamuje fatalne skoncentrowanie się na sobie, na swoich ranach, żalach, pretensjach, zamykające człowieka na pełnię osobowego życia"33. Akt przebaczenia stanowi zatem początek nowego etapu, w którym człowiek odzyskuje swoją wolność i może w nowej perspektywie określić siebie samego i nadać nowe znaczenia swojej biografii. „Bez przebaczenia człowiek pozostaje zamknięty

\footnotetext{
${ }^{30}$ Guerin, Wiek, 105-106.

31 Tamże, 108-109.

32 Por. Mrówka, Filozoficzny, 34.

33 Włodzimierz Zatorski, Przebaczenie (Kraków: SPES, 1997), 8.
} 
w swej winie, bez możliwości rozpoczęcia nowego życia. Przebaczenie nie oznacza wymazania zdarzenia z pamięci. Oznacza ofiarowanie, danie owego «możemy wszystko zacząć od początku», «możemy raz jeszcze»"34.

Kolejną konsekwencją braku przebaczenia są przykre uczucia: smutek, nienawiść oraz rozpacz, które w sposób szczególny zamykają człowieka na miłość, zatem ich dominacja uniemożliwia realizację jednej z najistotniejszych potrzeb ludzkich, związanych z funkcjonowaniem w relacjach. Według Ide,

gdy wybaczeniu powiemy „nie”, stanie się to źródłem naszego smutku. Uraza (dosłownie zgorzknienie serca, serce zgorzkniałe) jest owocem odrzuconego przebaczenia. [...] Odmowa przebaczenia może zasiać nienawiść i rozpacz. Rozpacz jest szczególnie głęboka, ponieważ chodzi o wybaczenie sobie samemu. [...] I przeciwnie: przebaczenie wyzwala w nas siłę kochania. Prawdziwa wolność to kochanie, ponieważ miłość powiększa serce ${ }^{35}$.

Autor zwrócił też uwagę na wpływ braku przebaczenia na umysł i wolę, a dokładniej na zaciemnienie umysłu i zafałszowanie percepcji. Podkreślona została także istotna psychologicznie konsekwencja nieprzebaczenia: ,zamknięcie się na przebaczenie, bycie obrażonym i znajdowanie w tym przyjemności, ciągłe wracanie do tego uderza w możliwość głębszych zmian istoty ludzkiej i ogranicza ją do niej samej. I odwrotnie, przebaczenie ma przynajmniej wartość psychologiczną, a jest nią niezamykanie się w sobie" ${ }^{{ }^{36}}$. Z tej perspektywy brak przebaczenia - tak sobie samemu, jak i innym - blokuje możliwość samorealizacji, związanej właśnie z wolnością i otwartością na proces zmian.

Przebaczenie, jako warunek dotarcia do siebie samego, stanowi także przedmiot analizy Augustyna Pelanowskiego. Autor podkreśla wartość odniesienia swojej historii życiowej do wymiaru duchowego i uświadomienia sobie stałej obecności Boga w każdym, nawet najtrudniejszym doświadczeniu biograficznym. Tylko w takiej perspektywie można, jego zdaniem, zaakceptować siebie samego jako istotę błądzącą, niedoskonałą czy słabą, a jednocześnie z odwagą i spokojem spoglądającą na siebie i swoje życie.

\footnotetext{
${ }^{34}$ Mrówka, Filozoficzny, 9.

35 Ide, Czy możliwe, 21.

36 Tamże, 36.
} 
Możemy podjąć tę wędrówkę, której celem jest docieranie do samego siebie, jako bezwarunkowe przyjęcie całej historii naszego życia. Mam tu na myśli akceptację tego wszystkiego, co się wydarzyło w życiu i zgodę na sposób, w jaki przeżywaliśmy każde wydarzenie w przeszłości. Nie ma miłości do siebie ten, kto nie zgadza się z pewnymi zaistniałymi wydarzeniami i kto nie może sobie wybaczyć błędów i niedoskonałości w przeżywaniu tych wydarzeń. Docieranie do siebie to życie z otwartymi bramami pamięci i nielękanie się żadnych wspomnień. Jest to możliwe, ale trzeba wierzyć, że za wszystkim, co dotąd przeżyliśmy, był obecny Bóg ${ }^{37}$.

Pelanowski wskazuje także na często występujący stan stłumionej złości, której źródło nie zostało przez człowieka odkryte we własnej biografii, a która wciąż o sobie przypomina w postaci chociażby niekontrolowanych wybuchów agresji. Autor opisuje konkretne etapy procesu wychodzenia $\mathrm{z}$ tego trudnego stanu emocjonalnego, jednocześnie ukazując miejsce przebaczenia $\mathrm{w}$ tym procesie.

Wyjście z takiego stanu, kiedy jesteśmy nabrzmiali od złości, nie jest szybkie i zaczyna się od odkrycia tych przeżyć, które naprawdę spowodowały oburzenie, gniew, złość, nienawiść, nieprzebaczenie, niepogodzenie itd. Później musi nastąpić „rozpracowanie” tych uczuć i najlepiej uczynić to nie samemu, lecz z kimś doświadczonym. Powinno to doprowadzić do przebaczenia (komuś, sobie), korekty postawy lub myślenia (przebaczenie sobie, zmiana wartościowania zachowań, oceniania wydarzeń, odkrycie nowego punktu widzenia na to, co się wydarzyło), zgody na to, co miało miejsce (akceptacja), uwielbienia Boga za łaskę przebaczenia, za zgodę i odkrycie nowego spojrzenia na rzeczywistość, a także za zmianę, jaka dokonała się w życiu ${ }^{38}$.

W procesie tym, oprócz wymiaru poznawczego, niezbędny jest także wymiar wdzięczności i uwielbienia Boga, co dopełnia i wzbogaca trud analizy i pracy nad sobą.

Proces wewnętrznego uzdrowienia związanego z przebaczeniem może być utrudniony przez niezdrowe, nieproporcjonalne czy wręcz patologiczne poczucie winy, będące skutkiem braku akceptacji siebie i własnych słabości w ogóle. „Człowiek o zdrowym poczuciu winy akceptuje siebie wraz

${ }^{37}$ Augustyn Pelanowski, Umieranie ożywiajace - czyli poradnik dla tych, którzy umierać nie chca, a umrzeć musza (Wrocław: Oficyna Wydawnicza „W misji”, 2005), 137.

38 Tamże, 229. 
z tym wszystkim, kim jest i co posiada, dostrzega swoje zalety i ceni je, ale umie też zgodzić się na swoje ograniczenia"39. Przeciwnie jest w przypadku niezdrowego poczucia winy związanego z perfekcjonizmem, w którym człowiek zamknięty jest na ulgę nawet w obliczu uzyskania przebaczenia od innych oraz od Boga. Wewnętrzna walka zyskuje szczególnie dramatyczny wyraz w przypadku zmagania się z zaburzeniem psychicznym. Tym większą radość budzą świadectwa wygranej walki i przebaczenia samemu sobie osób cierpiących na takie zaburzenia. Jednym ze świadectw są słowa autorki autobiograficznej książki o funkcjonowaniu z pogranicznym zaburzeniem osobowości i terapii z tym związanej:

Luty ustąpił miejsca marcowi, a temat mojego perfekcjonizmu i irracjonalnych oczekiwań względem siebie zdominował sesje z dr Padgettem. Zrozumiałam, że mogę być zadowolona z siebie, nawet jeśli nigdy nie będę doskonała, i powoli zmieniało się moje nastawienie do siebie i innych. Wraz z tym, jak stopniowo przechodziła mi nienawiść do samej siebie, poczułam olbrzymią ulgę. Znowu zaczęłam się śmiać. Rzadziej też miałam do siebie pretensje. Po raz pierwszy czułam, czym tak naprawdę jest wewnętrzny spokój ${ }^{40}$.

Słowa te akcentują najważniejsze efekty procesu przebaczenia samemu sobie i wzrostu samoakceptacji - wolność, ulgę, radość, otwartość, spokój i odprężenie. Zapewne bilans życia przeprowadzany w klimacie takich odczuć jest diametralnie różny od takiego, który przebiega $\mathrm{w}$ atmosferze irracjonalnego poczucia winy, napięcia, postawy usztywnienia i zablokowania na własne potrzeby.

\section{Pedagogiczne wspomaganie człowieka starszego na drodze do samoakceptacji}

Wspomaganie rozwoju starzejącego się człowieka jest naczelnym zadaniem gerontopedagogiki i w dużej mierze wiąże się ze stwarzaniem mu warunków dla twórczej refleksji nad swoją biografią, prowadzącej do integracji i uczenia się między innymi z własnych doświadczeń. W pracy z biografią powstaje także przestrzeń dla refleksji o przebaczeniu, a nierzadko także

39 Józef Augustyn, Sakrament pojednania (Kraków: Wydawnictwo M, 2009), 56.

${ }^{40}$ Rachel Reiland, Uratuj mnie. Opowieść o zlym życiu i dobrym psychoterapeucie (Poznań: Media Rodzina, 2006), 301. 
impuls do zmiany - w przypadku odkrycia w sobie wewnętrznych blokad związanych z odkrytym obszarem nieprzebaczenia. Rozważania te nie dotyczą pracy psychoterapeutycznej z osobą starszą, lecz wspomagania rozwoju osobistego, na przykład w formie warsztatów biograficznych. Zajęcia takie

łączą się z porządkowaniem zdarzeń i wspomnień z przeszłości, dokonywaniem pewnych podsumowań, bilansowaniem. Nie jest to proces ukierunkowany tylko na rejestrowanie obiektywnych faktów z życia, ale raczej ujawniający osobiste interpretacje. Przedstawianie historii własnego życia często łączy się ze zmianą wyobrażeń o życiu i odkrywaniem nowych wyjaśnień tych samych sytuacji i zdarzeń ${ }^{41}$.

Owe zmiany i odkrycia realizowane podczas zajęć grupowych (a więc dodatkowo w konfrontacji z innymi uczestnikami) w atmosferze bezpieczeństwa i akceptacji, mogą zaowocować refleksją nad tymi obszarami życia, które do tej pory były pomijane jako zbyt trudne, jak na przykład kwestie błędów z przeszłości. Twórcza refleksja autobiograficzna, stymulowana odpowiednio dobranymi technikami, może pomóc w osiągnięciu potrzebnego dystansu, zrozumienia, a nawet humorystycznego podejścia do tego, co do tej pory wydawało się jednoznacznie negatywnym doświadczeniem.

Według Beaty Bugajskiej i Celiny Timoszyk-Tomczyk w pełni świadoma koncentracja na pozytywnej reinterpretacji przeszłych doświadczeń

zakładałaby akceptację tego, co było, w całej pełni zarówno z tym, co było w niej radosne i optymistyczne, jak i z tym, co wzbudzało lęk, zagrożenie i pesymizm. [...] Niezależnie od tego, co się wydarzyło, jednostka może się rozwijać i czuć szczęśliwa. Dawałoby to szansę z jednej strony wykorzystania minionych doświadczeń, a z drugiej reinterpretacji i zdystansowania się do tego, co było w niej negatywne ${ }^{42}$.

Autorki, proponując scenariusz warsztatu rozwoju osobistego dla seniorów w oparciu o pracę z własną biografią, ukazują różne techniki, wspomagające wydobywanie z pamięci doświadczeń, nadawanie sensu własnej przeszłości i poszerzanie perspektywy czasowej. Taka praca z biografią stwarza warunki

${ }^{41}$ Kamila Lasocińska, Joanna Wawrzyniak, Autobiografia jako twórcze wyzwanie. Scenariusze warsztatów biograficznych (Warszawa: WA Żak, 2013), 16.

${ }^{42}$ Beata Bugajska, Celina Timoszyk-Tomczak, Podróż w czasie. Warsztat rozwoju osobistego osób starszych (Szczecin: Wydawnictwo Naukowe US, 2014), 79. 
dla lepszego samopoznania, zrozumienia swoich przeszłych decyzji i wyborów, potrzeb i ograniczeń, a to z kolei przybliża osobę do pełniejszej samoakceptacji.

Nieco inną metodę pracy biograficznej z ludźmi starszymi przedstawia Duccio Demetrio, proponując zabawę ze wspomnieniami w postaci gry autobiograficznej, w której fikcja przeplata się z rzeczywistością, a autor biografii bawi się nią i w dowolny sposób nią steruje. Poprzez zabawę tę uruchamiane jest między innymi kreatywne myślenie o alternatywnych scenariuszach własnej biografii, zaś dzięki fascynującej przygodzie spisywania wrażeń i wspomnień z biograficznej podróży ma szansę rozwinąć się energia i chęć do życia jej uczestników.

Przyjemność płynie z sięgania pamięcią wstecz, ze wspomnień traktowanych niekiedy z przymrużeniem oka i ironią, z rozważań nad tym, co szczęśliwym trafem lub na skutek niefortunnego zbiegu okoliczności, stało się w przeszłości naszym udziałem i co stanowi świadectwo naszego życia. Pozostaje nam jedynie pogodzić się z nim, przyjąć i zaakceptować pomimo rozczarowania lub niezadowolenia ${ }^{43}$.

Działanie takie umożliwia spojrzenie na swoje życie z większą otwartością, dystansem i humorem.

Podobne założenia przyjmują w swojej propozycji warsztatów biograficznych Kamila Lasocińska i Joanna Wawrzyniak, pisząc w następujący sposób o zabawie z biografią:

spojrzenie na znane i stare zdarzenia w inny niż dotychczas sposób, próba odwrócenia znanej sytuacji, zaplanowanie innego końca, dostrzeżenie innych skutków własnego postępowania to - oprócz samego procesu przypominania cel zabawy z biografią. Każda zabawa powinna być twórcza, dlatego ważne jest nie tyle wierne odzwierciedlenie rzeczywistości, ile poszukiwania i pobudzanie do kreacji ${ }^{44}$.

W tego rodzaju pracy zasadnicze wydaje się być właśnie owo „spojrzenie w inny niż dotychczas sposób" na doświadczenia, poszerzenie perspektywy i przekroczenie schematów także w podejściu do samego siebie, co może

${ }_{43}$ Duccio Demetrio, Zabawa na tle życia - gra autobiograficzna w edukacji dorostych (Kraków: OW Impuls, 1999), 9.

${ }^{44}$ Lasocińska, Wawrzyniak, Autobiografia, 72. 
zaowocować większą wyrozumiałością wobec siebie i innych. Może też pomóc w definitywnym zamknięciu pewnych etapów życia i oderwaniu się od hamujących rozwój osobisty sposobów myślenia o swojej biografii.

Osoba w wieku senioralnym jest samodzielnym podmiotem, który może nadawać kierunek własnemu rozwojowi, jest autorem i narratorem opowieści o swoim życiu. Sama wybiera sposoby interpretacji tej opowieści. Posiada związany z wewnętrznymi zasobami oraz doświadczeniem życiowym potencjał, aby prawdziwie twórczo i konstruktywnie przeżywać każdy dzień życia. Ponadto, zgodnie z wyżej przytoczonymi ujęciami teoretycznymi, tak zwany trzeci wiek stanowi szczególnie dobry czas na twórczą refleksję egzystencjalną i wykorzystanie życiowej mądrości również w pracy nad samoakceptacją.

$Z$ wielu powodów w naszej codzienności spotykamy inny, stereotypowy obraz osoby starszej, jako zmagającej się z wewnętrznymi konfliktami, ulegającej bierności i rezygnacji, czy też trzymającej się sztywnych schematów myślenia i zachowań, utrudniających otwarcie się na zmianę, w tym także na możliwość przebaczenia. Jednocześnie nie można sprowadzić umiejętności przebaczenia wyłącznie do zaprojektowanego działania w zakresie rozwoju osobistego. Niemniej jednak propozycje praktyków - pedagogów i psychologów - prowadzących zajęcia wspomagające rozwój ludzi starszych, mogą stanowić wartościową inspirację dla osób poszukujących odpowiedzi na następujące pytania: w jaki sposób wspierać dążenie seniorów do samorealizacji, lepszej jakości życia, osiągnięcia dobrostanu czy też pełni życia? Jak stymulować twórczy i edukacyjny potencjał osoby starszej? I wreszcie: jak wspomagać proces osiągania samoakceptacji i pogodzenia $\mathrm{z}$ własną historią życia?

\section{Self-forgiveness in the Context of Personal Development in Old Age (Summary)}

The article presents the issue of self-forgiveness in the context of personal development in old age. This process is seen as very important for a constructive life review and high quality of life. Initially, there is analysis of the concept of forgiveness, which derives mostly from the Judeo-Christian tradition. Then, the process is related to the human aging and different attitudes and obstacles. In the final part of the article there is a reference to the educational practice, related to supporting the development of the elderly in biographical work.

Key words: self-forgiveness; life review; aging; self-acceptance; biography. 


\section{Przebaczenie sobie w kontekście rozwoju osobistego w wieku senioralnym (Streszczenie)}

W artykule podjęta została problematyka procesu przebaczenia samemu sobie w kontekście rozwoju osobistego w wieku senioralnym. Proces ten jawi się jako zasadniczy dla przygotowania do konstruktywnego i twórczego bilansu życia na jego ostatnim etapie, a także utrzymania wysokiego poziomu jakości życia. Początkowo ma miejsce analiza pojęcia przebaczenia, które jest najmocniej zakorzenione w tradycji judeochrześcijańskiej, choć analizowane jest także w wymiarze świeckim. Następnie proces ten zostaje odniesiony do starzenia się człowieka i związanych z tym postaw i przeszkód. W końcowej części artykułu rozważania odnoszą się do praktyki pedagogicznej, związanej ze wspomaganiem rozwoju osób dojrzałych, w tym z pracą biograficzną nad osiąganiem samoakceptacji i integracji własnych życiowych doświadczeń.

Słowa kluczowe: przebaczenie samemu sobie; bilans życia; starzenie się; samoakceptacja; biografia.

\section{Bibliografia}

Augustyn, Józef. Sakrament pojednania. Kraków: Wydawnictwo M, 2009.

Bugajska, Beata, Celina Timoszyk-Tomczak. Podróż w czasie. Warsztat rozwoju osobistego osób starszych. Szczecin: Wydawnictwo Naukowe US, 2014.

Demetrio, Duccio. Zabawa na tle życia - gra autobiograficzna w edukacji dorostych. Kraków: OW Impuls, 1999.

Giulianini, Annalisa. O przebaczeniu czyli jak uleczyć duszę. Kraków, Bratni Zew Wydawnictwo Franciszkanów, 2010.

Grün, Anselm. Przebacz samemu sobie. Kraków: WAM, 2003.

Guerin, Paul. Wiek dojrzaty jako wyzwanie duchowe. Kraków: eSPe, 2003.

Ide, Pascal. Czy możliwe jest przebaczenie? Kraków: WAM, 2000.

Matlakiewicz, Alina, Hanna Solarczyk-Szewc. Dorośli ucza się inaczej. Toruń: Wydawnictwo CKU, 2005.

Mietzel, Gerd. Wprowadzenie do psychologii. Gdańsk: GWP, 2003.

Mrówka, Kazimierz. Filozoficzny sens przebaczenia. Tarnów: Wydawnictwo Biblos, 2008.

Lasocińska, Kamila, Joanna Wawrzyniak. Autobiografia jako twórcze wyzwanie. Scenariusze warsztatów biograficznych. Warszawa: WA Żak, 2013. 
The New Oxford Dictionary of English, red. Judy Pearsall. Oxford: Clarendon Press, 1998.

Pelanowski, Augustyn. Umieranie ożywiające - czyli poradnik dla tych, którzy umierać nie chca, a umrzeć muszą. Wrocław: Oficyna Wydawnicza „W misji”, 2005. Reiland, Rachel. Uratuj mnie. Opowieść o złym życiu i dobrym psychoterapeucie. Poznań: Media Rodzina, 2006.

Steuden, Stanisława. Psychologia starzenia się i starości. Warszawa: PWN, 2011. Stownik Języka Polskiego, t. 2, red. Marek Szymczak. Warszawa: PWN, 2002. Zatorski, Włodzimierz. Przebaczenie. Kraków: SPES, 1997. 